\title{
Estrogen Actions Throughout the Brain
}

\author{
BRUCE McEwen \\ Harold and Margaret Milliken Hatch Laboratory of Neuroendocrinology, \\ The Rockefeller University, New York, New York 10021
}

\begin{abstract}
Besides affecting the hypothalamus and other brain areas related to reproduction, ovarian steroids have widespread effects throughout the brain, on serotonin pathways, catecholaminergic neurons, and the basal forebrain cholinergic system as well as the hippocampal formation, a brain region involved in spatial and declarative memory. Thus, ovarian steroids have measurable effects on affective state as well as cognition, with implications for dementia. Two actions are discussed in this review; both appear to involve a combination of genomic and nongenomic actions of ovarian hormones. First, regulation of the serotonergic system appears to be linked to the presence of estrogen- and progestin-sensitive neurons in the midbrain raphe as well as possibly nongenomic actions in brain areas to which serotonin neurons project their axons. Second, ovarian hormones regulate synapse turnover in the CA1 region of the hippocampus during the 4- to 5-day estrous cycle of the female rat. Formation of new excitatory synapses is induced by estradiol and involves $\mathrm{N}$-methyl-D-aspartate (NMDA) receptors, whereas downregulation of these synapses involves intracellular progestin receptors. A new, rapid method of radioimmunocytochemistry has made possible the demonstration of synapse formation by labeling and quantifying the specific synaptic and dendritic molecules involved. Although NMDA receptor activation is required for synapse formation, inhibitory interneurons may play a pivotal role as they express nuclear estrogen receptor-alpha (ER $\alpha$ ). It is also likely that estrogens may locally regulate events at the sites of synaptic contact in the excitatory pyramidal neurons where the synapses form. Indeed, recent ultrastructural data reveal extranuclear ER $\alpha$ immunoreactivity within select dendritic spines on hippocampal principal cells, axons, axon terminals, and glial processes. In particular, the presence of ER in dendrites is consistent with a model for synapse formation in which filopodia from dendrites grow out to find new synaptic contacts and estrogens regulate local, post-transcriptional events via second messenger systems.
\end{abstract}

\section{Introduction}

Most studies of estrogen action in brain have focused on reproduction. The majority of these studies have dealt with animal models in which evidence accumulating over more than 30 years has shown that estrogens target the brain of experimental animals (Pfaff, 1980). Now, medical science has recognized that the brain is one of the organs of the body that suffers from the loss of estrogen after surgical or natural menopause and that damage from stroke and neurodegeneration in dementia may be retarded by estrogen actions. Indeed, with 
increasing life expectancy during the 20th century, women are likely to live a substantial part of their lives in a state of estrogen deficiency. Although hot flushes are, for many women, the most-dramatic and noticeable consequence of loss of ovarian hormones, some women experience, at surgical or natural menopause, difficulties in remembering names and other information important for daily life as well as deficits in fine motor coordination and reaction times and feelings of depression and anxiety (McEwen and Alves, 1999). Loss of bone calcium and osteoporosis are other consequences that have led many women to take estrogen replacement therapy (ERT) at the menopause. Likewise, the loss of protection of the coronary arteries, leading postmenopausal women to increased risk for cardiovascular disease, is another result of estrogen deficiency that has reinforced the value of ERT. Thus, the somewhat-delayed recognition of the brain as an important estrogen target provides another compelling reason to investigate the value of ERT for states of estrogen deficiency.

Although most of the animal studies cited above focused on estrogen actions on the hypothalamus affecting ovulation and reproductive behavior, it is now apparent in animal models and clinical studies that estrogens exert many actions outside of reproductive function, including actions on brain areas that are important for learning and memory and for emotions and affective state as well as motor coordination and pain sensitivity. These effects reflect the actions of estrogens on a large number of brain areas outside of the hypothalamus, such as the midbrain and brain stem neurons that produce serotonin and catecholamines, spinal cord, cerebral cortex, and hippocampus. The problem in these brain regions has been to recognize the receptors and mechanisms by which estrogens produce their effects.

This review will focus on two aspects. First, the cellular and molecular mechanisms by which estrogens produce their diverse effects on the brain. Second, the brain regions and cell types in which estrogens produce their effects, emphasizing new knowledge regarding estrogen actions outside of the hypothalamus and pituitary gland. The serotonin system will be discussed as an example as well as the hippocampus. We will discuss the actions of estrogens in regulating synapse formation in hippocampus because they reflect a novel, nonreproductive action of estrogens related to cognitive function that is relevant for postmenopausal changes. Furthermore, these actions also illustrate the emerging evidence that estrogens act via mechanisms other than the classical cell nuclear estrogen receptors (ERs).

\section{Intracellular Mechanisms of Estrogen Action in the Central Nervous System}

\section{A. INTRACELLULAR ESTROGEN RECEPTORS}

In the early 1960s, ERs were identified that bind to DNA and regulate gene expression (Jensen and Jacobson, 1962). Radioactive estrogens were used to 
identify ERs inside of the cell nuclei. The identification and mapping of cells that contain ERs were extended from the uterus and mammary glands to the brain and pituitary gland (Pfaff, 1980). At first, only ERs in the hypothalamus and pituitary gland were studied because they were the most obvious and also the most obviously related to estrogen actions on reproduction. Eventually, however, nerve cells containing ERs were recognized in brain regions like the hippocampus, cerebral cortex, midbrain, and brainstem. We are now aware of two types of intracellular ER, ER $\alpha$ and ER $\beta$ (see McEwen and Alves, 1999, for summary).

Measurements of mRNA for $\operatorname{ER} \alpha$ and $\operatorname{ER} \beta$ reveal distributions in the body that differ quite markedly from each other, with moderate to high expression of $\mathrm{ER} \alpha$ in pituitary, kidney, epididymus, and adrenal; moderate to high expression of ER $\beta$ in prostate, lung, bladder, and brain; and overlapping high expression in ovary, testis, and uterus (Kuiper et al., 1998). Isoforms of ER $\beta$ are now being identified (see McEwen and Alves, 1999, for summary). The best characterized of these splice variants is ER $\beta 2$, as opposed to the originally identified isoform, $\mathrm{ER} \beta 1$. ER $\beta 2$ appears to have a lower affinity for estrogens than ER $\beta 1$, presumably due to an 18 amino acid insertion in the ligand-binding domain (Maruyama et al., 1998). There are other splice variants of $\mathrm{ER} \beta$ with differential expression in brain and other tissues, including a variant missing Exon 4 that does not bind estradiol in hippocampus (Price et al., 2000).

In brain, the distribution of $\mathrm{ER} \alpha$ is fairly well established but there is less certainty surrounding the localization of ER $\beta$. Autoradiographic maps of ${ }^{3} \mathrm{H}$ estradiol uptake and retention in brain (Stumpf and Sar, 1976; Pfaff, 1980) are presumed to reflect binding to all forms of the ER, particularly the ER $\alpha$ and ER $\beta 1$ isoforms, which have similar, high affinities for $17 \beta$ estradiol (Kuiper $e t$ al., 1998). In situ hybridization data indicate widespread distribution of $\mathrm{ER} \beta$ mRNA throughout much of the brain, including olfactory bulbs, cerebellum, and cerebral cortex (Kuiper et al., 1997,1998). Results from immunocytochemical studies for $\mathrm{ER} \beta$ indicate a more-restricted localization of detectable protein, although the antisera that are currently available do not always provide specific signals in some brain areas (see McEwen and Alves, 1999, for discussion). Recent evidence shows good agreement between ER $\beta$ mRNA levels and ER $\beta$ immunoreactivity with a polyclonal antibody to the C terminus of ER $\beta$ (Shughrue and Merchenthaler, 2001). In particular, colocalization of ER $\beta$ mRNA with cell nuclear ER $\beta$ immunoreactivity was demonstrated in the rat cerebral cortex, paraventricular nuclei of the hypothalamus, and hypothalamic preoptic area (Shughrue and Merchenthaler, 2001). Other brain regions remain to be studied for such co-localization.

The introduction of ${ }^{125}$ I estrogen to label ER with a higher specific radioactivity has revealed the presence of binding sites not previously detected using ${ }^{3} \mathrm{H}$ estradiol (Shughrue et al., 1999; Shughrue and Merchenthaler, 2000). In hippocampus, labeling was evident in the interneurons previously seen to contain 
$\mathrm{ER} \alpha$ by other methods, with higher concentrations in ventral hippocampus (Shughrue and Merchenthaler, 2000). However, the most important difference from ${ }^{125} \mathrm{I}$ estrogen labeling of ER was the detection of label in pyramidal cells of CA1-CA3 in the ventral hippocampus. In parallel studies of ER $\alpha$ and $-\beta$ mRNA, there was a similar dorsal-to-ventral gradient as that seen for ${ }^{125} \mathrm{I}$ estrogen binding and the $\operatorname{ER} \alpha$ signal appeared to be stronger than that for $\operatorname{ER} \beta$ (Shughrue and Merchenthaler, 2000). Thus, the greater sensitivity of ${ }^{125} \mathrm{I}$ estrogen labeling of ER reveals sites that may indicate locations of estrogen actions in hippocampal pyramidal cells, particularly in pyramidal cell nuclei of the ventral hippocampus.

$\mathrm{ER} \alpha$ and $\operatorname{ER} \beta$ are similar not only in affinity for a number of estrogens and estrogen antagonists (Kuiper et al., 1998) but also in their ability to regulate genes in which the estrogen response element (ERE) is the primary site of interaction (Paech et al., 1997). The major differences between $\operatorname{ER} \alpha$ and $\operatorname{ER} \beta$ concern their ability to regulate transcription via the AP-1 response element. With AP-1, estradiol $17 \beta$ activated transcription with $\mathrm{ER} \alpha$, whereas it failed to activate transcription with $\mathrm{ER} \beta$ and was able to cause inhibition. In contrast, with AP-1, nonsteroidal estrogen antagonists such as tamoxifen activated transcription with ER $\beta$ and did so to a lesser extent with ER $\alpha$ (Paech et al., 1997).

$\mathrm{ER} \alpha$ and $\operatorname{ER} \beta$ can form heterodimers when expressed in the same cells, thus giving rise to additional possible variants as far as gene regulation (Pettersson $e t$ al., 1997). Thus far, endogenous colocalization of $\operatorname{ER} \alpha$ and $\operatorname{ER} \beta$ has been demonstrated in the hypothalamic preoptic area, bed nucleus of the stria terminalis, and medial amygdaloid nucleus (Hrabovszky et al., 1998) and probably exists in other brain regions, including midbrain raphe (see below).

Nonsteroidal estrogen antagonists exert agonist-like effects on some neurochemical or functional endpoints in the rat brain and antagonistic effects on others. Antagonistic effects for CI-628, a tamoxifen-like estrogen antagonist, were seen in terms of blockade of estrogen-induced progestin receptor induction and lordosis behavior (Roy et al., 1979; Meisel et al., 1987). Agonist-like effects of CI-628 were seen for induction of choline acetyltransferase in basal forebrain and repression of monoamine oxidase A in amygdala (Luine and McEwen, 1977). Recently, CI-628 was shown to block estrogen-induced synapse formation in the hippocampus without having any agonist-like effects (McEwen et al., 1999b; Brake et al., 2001).

One important implication of these findings concerning the mixed agonist and antagonist role of some estrogen antagonists is that nonsteroidal antiestrogens, like CI-628 and possibly also tamoxifen and raloxifene, will not have uniformly agonistic or antagonistic effects on the diversity of actions that estrogens normally produce in the brain. This has implications for the therapeutic applications of such agents and requires a separate study of the actions of these agents on each endpoint of estrogen action. 
Unfortunately, the molecular basis of these effects is not clear. Although anti-estrogens function as antagonists for $\operatorname{ER} \alpha$ and $\operatorname{ER} \beta$ via the ERE, these same anti-estrogens worked through the AP-1 response element to activate transcription via $\operatorname{ER} \beta$ also, to a lesser extent, via $\mathrm{ER} \alpha$ (Paech et al., 1997). Yet, with AP-1, estradiol $17 \beta$ activated transcription with $\mathrm{ER} \alpha$, whereas it failed to activate transcription with $\operatorname{ER} \beta$ and was able to cause inhibition (Paech et al., 1997). Thus, to account for parallel agonist-like actions of estrogen antagonists, such as we have demonstrated for choline acetyltransferase and monoamine oxidase, it is necessary to postulate that $\mathrm{ER} \alpha$ is the receptor involved and that it uses the AP-1 response element where both estradiol and CI-628 can have agonistic-like actions.

\section{B. NOVEL ESTROGEN ACTIONS VIA NON-NUCLEAR RECEPTORS}

Rapid estrogen effects on neuronal excitability (Kelly et al., 1977; Nabekura et al., 1986) have been known for a number of years. Yet, only recently has this topic emerged in full force as an alternative aspect of estrogen action that involves interactions of ERs with second messenger systems and potentially novel types of ERs (Kelly and Wagner, 1999; Brinton, 2001; Kelly and Levin, 2001; Lee and McEwen, 2001).

The variety of nongenomic estrogen effects includes 1) rapid actions on excitability of neuronal and pituitary cells; 2) the activation by estrogens of cyclic AMP and mitogen-activated protein kinase (MAP kinase) pathways that affect activity of such targets as kainate and insulin-like growth factor-1 (IGF-1) receptors; 3 ) estrogen actions that involve modulation of $\mathrm{G}$ protein coupling and affect calcium currents and gonadotropin-releasing hormone $(\mathrm{GnRH})$ release; 4) effects on calcium channels and calcium ion entry; and 5) protection of neurons from damage by excitotoxins and free radicals (Kelly and Wagner, 1999; Brinton, 2001; Kelly and Levin, 2001; Lee and McEwen, 2001).

For estrogen actions on some aspects of calcium homeostasis, certain aspects of second messenger systems, and some features of neuroprotection, a novel receptor mechanism is implicated in which stereospecificity for $17 \beta$ over $17 \alpha$ estradiol is replaced by a broader specificity for the 3 hydroxyl group on the A ring ( McEwen and Alves, 1999; Lee and McEwen, 2001). On the other hand, there is also evidence that $\operatorname{ER} \alpha$ and $\operatorname{ER} \beta$ are capable of participating in second messenger cascades involving second messenger activation and $\mathrm{G}$ protein coupling (Razandi et al., 1999; Kelly and Levin, 2001). Besides $\mathrm{ER} \alpha$ and $\mathrm{ER} \beta$, membrane ERs have been reported on pituitary, uterine, ovarian granulosa cell, spermatozoa, testes, and liver cell membranes. However, these have been only partially characterized in binding studies and only in a few cases have been shown to be linked to signal 
transduction mechanisms (for a review, see McEwen and Alves, 1999; Kelly and Levin, 2001; Lee and McEwen, 2001).

Finally, estrogenic compounds protect nerve cells from damage by excitotoxins and free radicals in novel ways (McEwen and Alves, 1999; Lee and McEwen, 2001). In this realm are neuroprotective effects that appear to be mediated via classical genomic receptors, based upon the fact that they can be blocked by estrogen antagonists. But other actions are not blocked by these antagonists and appear to involve a novel mechanism in which estradiol $17 \alpha$ is as potent as estradiol 17 $\beta$ (Green et al., 1997; Lee and McEwen, 2001). These actions of estrogens, albeit in 100-nM to micromolar concentrations, reduce the production of or actions of free radicals in causing cell damage and promoting cell death through apoptosis. Mitochondria are major targets of estrogen action. Estrogen effects stabilize mitochondrial membrane potentials, prevent adenosine triphosphate (ATP) depletion, and reduce the generation of oxygen free radicals (Mattson et al., 1997; Wang et al., 2001).

\section{Estrogen Actions Throughout the Central Nervous System}

We now know that ovarian steroids have numerous effects on the brain throughout the lifespan, beginning during gestation and continuing on into senescence. Estrogens participate in the sexual differentiation of the brain during early embryonic or neonatal life. These effects undoubtedly involve the classical intracellular ERs (McEwen, 1983; Auger et al., 2000). The process of sexual differentiation involves the secretion of testosterone in fetal or early neonatal life and the actions of testosterone either through androgen receptors or via aromatization to estrogen in the defeminization and masculinization of brain structures and function (Goy and McEwen, 1980; Naftolin, 1994). Although initially believed to be confined to the hypothalamus, structural and functional sex differences have been found in higher cognitive centers and in sensory and autonomic ganglia as well as structures of the limbic system of the brain and the midbrain, brainstem, and basal forebrain structures (for a review, see McEwen and Alves, 1999).

Estrogens affect areas of the brain that are not primarily involved in reproduction, such as the basal forebrain cholinergic system, the hippocampus and cerebral cortex, the caudate-putamen, midbrain raphe and brainstem locus coeruleus, and the spinal cord. These systems are involved in a variety of estrogen actions on mood, locomotor activity, pain sensitivity, vulnerability to epilepsy, and attentional mechanisms and cognition (for a review, see McEwen and Alves, 1999).

Functional or structural sex differences exist in a number of these brain regions (Fischette et al., 1984; Kimura, 1992; Bazzett and Becker, 1994; Witelson et al., 1995). For example, developmentally programmed sex 
differences in hippocampal structure may help explain differences in the strategies that male and female rats use to solve spatial navigation problems (Williams and Meck, 1991). A similar sex difference in spatial problemsolving is reported in humans (Kimura, 1992). During the period of development when testosterone is elevated in the male, aromatase activity and ERs are transiently expressed in hippocampus. Recent data on behavior and synapse induction strongly suggest that this pathway is involved in the masculinization or defeminization of hippocampal structure and function.

In spite of the paucity of $\mathrm{ER} \alpha$ outside the hypothalamus, hypothalamic preoptic region, and amygdala, estrogens have effects on many other brain regions and neurochemical systems involved in a host of nonreproductive brain functions. The expression of ER $\beta$ mRNA in many of these brain regions has raised the possibility of functional ERs in these brain areas. At the same time, the presence of a few ER $\alpha$-containing nerve cells has led to the discovery, for example in the hippocampus, that these few nerve cells can have powerful trans-synaptic effects on neighboring neurons. As will be discussed in detail below, treatment of ovariectomized rats with estradiol $17 \beta$ induces certain hippocampal neurons to form new synaptic connections with other nerve cells. These estrogen effects appear to be attributable, at least in part, to intracellular ER $\alpha$ in inhibitory interneurons (see below). In addition, the rapidity and structure-activity profile of some of these effects have raised questions about the possible "nontraditional" and even nongenomic actions of estrogens in some brain regions. For example, actions of estrogens on dopaminergic activity in the corpus striatum and nucleus accumbens appear to be mediated by membrane actions in the absence of any documented expression of either ER $\alpha$ or $\mathrm{ER} \beta$ in cell nuclei of these brain regions (Maus et al., 1990; Mermelstein et al., 1996).

Estrogen actions upon cholinergic, noradrenergic, serotonergic, and hypothalamic dopaminergic systems, on the other hand, are likely to be mediated by known nuclear intracellular ER $\alpha$ or ER $\beta$ (see McEwen and Alves, 1999, for summary). This will be decribed for the serotonin system. The spinal cord also has intracellular $\operatorname{ER} \alpha$ and $\operatorname{ER} \beta$ but the reported effects on nociception and analgesia do not directly relate to those receptor sites in enkephalin-expressing spinal neurons. Moreover, endothelial cells and at least some glial cells must be considered as targets for estrogen action that affect glucose uptake and mechanisms that support the replenishment of cell membranes and possibly also synaptogenesis and other forms of structural plasticity (see McEwen and Alves, 1999; McEwen et al., 2001, for summary). We now will examine two systems involving actions of estrogens on brain areas that are involved in many functions beyond those specifically concerned with reproduction, namely, the midbrain serotonin system and the hippocampus. 


\section{Estrogen Actions on Midbrain Raphe and Serotonin Receptors in Forebrain}

The serotonin system projects widely to many brain regions and is concerned with the regulation of many aspects of brain function, ranging from autonomic nervous system reactivity to mood, aggression, and cognitive function (Jacobs, 1994; Higley and Linnoila, 1997; Rubinow et al., 1998; Bethea et al., 1999). Ovarian steroids regulate the serotonin system of rodents and primates (Alves et al., 1998; Bethea et al., 1999), but important differences exist in the relationship between detectable intracellular ERs and the serotonergic neurons.

In primates, both $\mathrm{ER} \alpha$ and $\mathrm{ER} \beta$ are found in midbrain 5HT neurons and estrogens regulate tryptophan hydroxylase as well as progestin receptor expression (Bethea et al., 1999). In rats, $\mathrm{ER} \alpha$ is found in non-5HT neurons, where estrogen regulates expression of progestin receptors (Alves et al., 1998) but not expression of tryptophan hydroxylase (S.E. Alves, unpublished data). Sex differences are found in the ability of estrogen treatment to induce progestin receptors (Alves et al., 1998). In mice, both $\operatorname{ER} \alpha$ and $\operatorname{ER} \beta$ are present and functional in the midbrain. ER $\alpha$ is expressed in 5HT neurons that also express progestin receptors (Alves et al., 2000). Yet, the $\alpha$ ERKO mouse also shows estrogen induction of progestin receptors in midbrain raphe, implying that another ER, most likely ER $\beta$, is involved (Alves et al., 2000) (Figure 1).

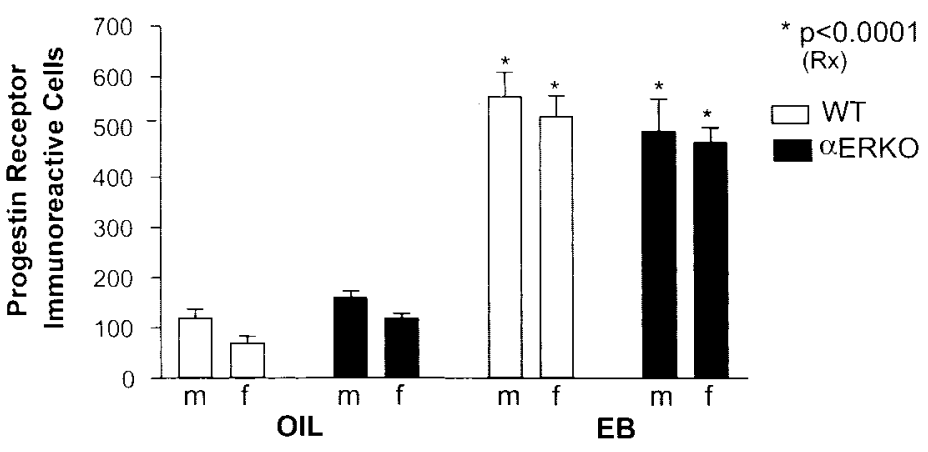

FIG. 1. Number of progestin receptor (PR) immunoreactive cells counted in the dorsal raphe nucleus (A) and median raphe nucleus (B) of wild-type (WT) and $\alpha$ ERKO mice of both sexes. Estradiol benzoate (EB) treatment induces PR in both sexes of both genotypes. Although EB induces PR in both genotypes, the significant interaction between treatment and genotype in both dorsal $(\mathrm{F}(1,16)=4.73, \mathrm{p}<.045)$ and median $(\mathrm{F}(1,16)=9.33, \mathrm{p}<.008)$ raphe nuclei indicates that the magnitude of PR induction by EB over baseline levels was less in the $\alpha$ ERKO animals. No significant gender differences were found. We conclude that another ER besides $\mathrm{ER} \alpha$, most likely $\mathrm{ER} \beta$, mediates the effects of $\mathrm{EB}$ in the raphe nuclei. [Reprinted with permission from Alves SE, McEwen BS, Hayashi S, Korach KS, Pfaff DW, Ogawa S 2000 Estrogen-regulated progestin receptors are found in the midbrain raphe but not hippocampus of estrogen receptor alpha (ER $\alpha$ ) gene-disrupted mice. J Comp Neurol 427:185-195. Copyright Wiley-Liss, Inc., a subsidiary of John Wiley \& Sons, Inc.] 
Estrogens also regulate other components of the serotonin system besides tryptophan hydroxylase. In midbrain raphe of primates, estrogen treatment decreased serotonin transporter mRNA expression (Bethea et al., 1999). In macaque hypothalamus, estrogen treatment decreased expression of the 5HT2C receptor in a number of hypothalamic nuclei (Gundlah et al., 1999). In rat brain, 32-hour estrogen treatment increased levels of 5HT2A mRNA in dorsal raphe and 5HT2A receptor binding in frontal, cingulate, and primary olfactory cortex as well as in nucleus accumbens (Sumner and Fink, 1998) (Figure 2). There were no sex differences in this induction (Sumner and Fink, 1998). Another study on rats reported that a 24-hour estrogen treatment increased 5HT2A mRNA levels in amygdala, hippocampus, accumbens, and a number of cortical areas, while

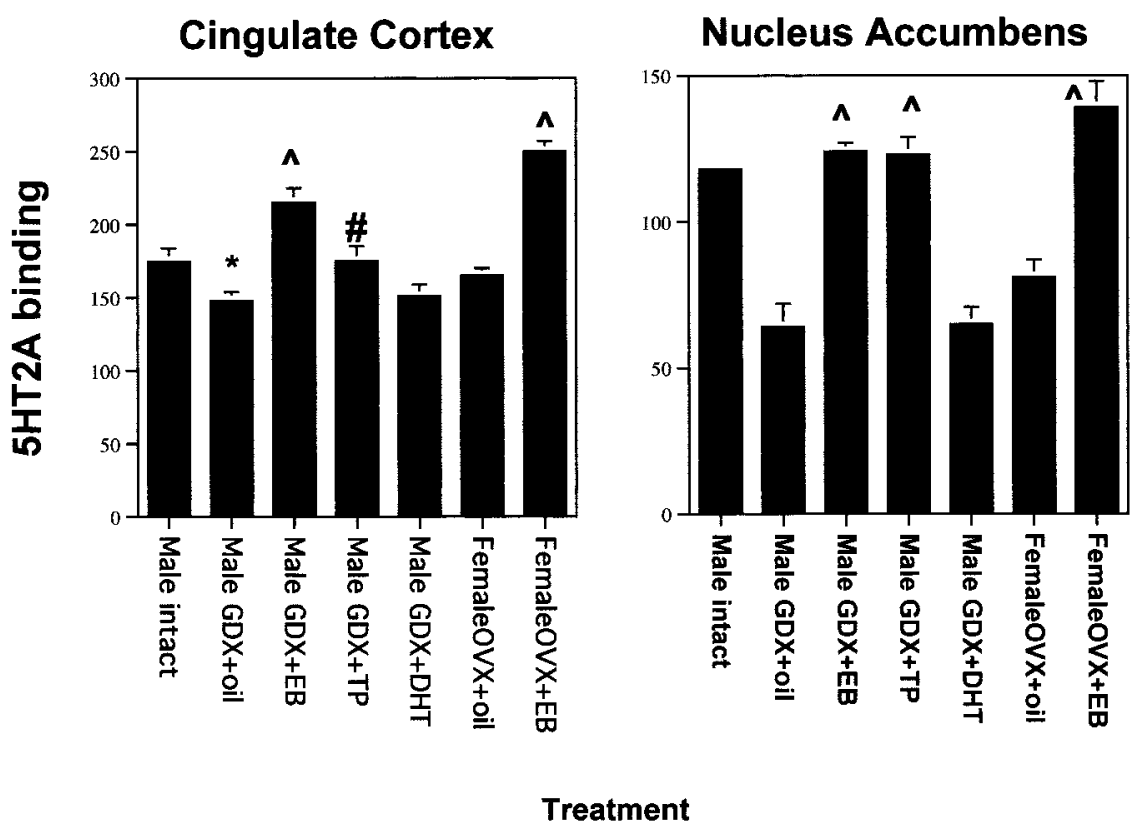

FIG. 2. Serotonin 5HT2A receptor binding in the cingulate cortex and nucleus accumbens of male and female rats after gonadectomy and treatment with either oil vehicle, estradiol benzoate (EB), testosterone propionate (TP), or dihydrotestosterone (DHT). These two brain areas are not normally considered to be estrogen or androgen target areas but the post-synaptic 5HT2A receptor levels are elevated in both males and females by $\mathrm{EB}(\wedge \mathrm{p}<.005)$ and in males by TP $(\# \mathrm{p}<.05$ for cingulate; $\wedge \mathrm{p}<.005$ for accumbens) but not by DHT. There is a significant effect of gonadectomy in males $(\mathrm{p}<.05)$. This suggests that estrogens work equally in both sexes and the aromatase pathway may be involved in the TP effects, although the nature of the ERs that mediate these effects remains uncertain. [Redrawn from Sumner BEH, Fink G 1998 Testosterone as well as estrogen increases serotonin ${ }_{2 \mathrm{~A}}$ receptor mRNA and binding site densities in the male rat brain. Mol Brain Res 59:205-214.] 
decreasing 5HT1A mRNA levels in many of the same brain regions of several strains of rats differing in anxiety-related behaviors (Osterlund et al., 1999). Chronic (2-week) estrogen treatment also decreased 5HT1A receptor binding in amygdala, hippocampus, and cerebral cortex (Osterlund et al., 2000). Yet, in this study, the effects of estrogen on 5HT1A mRNA levels, evident after acute estrogen treatment, disappeared with the chronic treatment that decreased 5HT1A receptor binding.

The actions of estrogen on the 5HT1A receptor system illustrate the complexities of distinguishing between traditional genomic effects of estrogens and those involving a non-nuclear action. Estrogen treatment causes a rapid decrease in coupling to $\mathrm{G}$ proteins that reduces the inhibitory effect of 5HT1A agonists on lordosis behavior, hyperphagia, and oxytocin and corticotropin (ACTH) responses (Raap et al., 2000; Mize et al., 2001). The rapid, estrogeninduced decrease in 5HT1A efficacy has been assessed by measuring radiolabeled GTP $\gamma$ S binding (Mize et al., 2001) after treatment with estrogen in homogenates of hippocampus and frontal cortex. Estradiol $17 \beta(E C 50=25 \mathrm{nM})$ showed a dose-dependent ability to decrease GTP $\gamma \mathrm{S}$ binding. This effect was mimicked by diethylstilbestrol but not by the less-potent estrogens, estradiol $17 \alpha$ and estriol, and was blocked by the estrogen antagonist, ICI 182780 (Mize et al., 2001). These results are consistent with the involvement of a non-nuclear form of $\mathrm{ER} \alpha$ or $\mathrm{ER} \beta$, as discussed above.

\section{Estrogen Actions in Hippocampus re: Cognitive Function and Memory Processes}

The hippocampus is a brain region that is involved in episodic, declarative, contextual, and spatial learning and memory as well as serving as a component in the control of autonomic and vegetative functions such as ACTH secretion (Jacobson and Sapolsky, 1991; Eichenbaum and Otto, 1992; Phillips and LeDoux, 1992). The hippocampus is also vulnerable to damage by stroke and head trauma and susceptible to damage during aging and repeated stress (Sapolsky, 1992). Among the most novel and fascinating effects of estrogen are those on cognitive function. Estrogen effects on memory have been reported in animal models and in studies on humans (McEwen and Alves, 1999). The memories affected are ones in which the hippocampus plays a role along with the basal forebrain cholinergic system and other neurochemical systems. Rather than one estrogen-regulated process, many types of estrogen actions on a number of neurochemical and neuroanatomical substrates and a number of molecular mechanisms are likely to underlie the actions of estrogens on cognition and other aspects of behavior such as mood, pain perception, and nociception.

One of the processes regulated by ovarian hormones is the cyclic formation and breakdown of excitatory synapses in the hippocampus (Woolley et al., 1990). 
This finding was surprising because the hippocampus is a brain region in which cell nuclear ERs are present in scattered inhibitory interneurons but not in principal neurons where synapse formation occurs (Weiland et al., 1997). Yet, the effects of ovarian hormones on synaptic turnover were as impressive in the hippocampus as those in the ventromedial hypothalamus (Carrer and Aoki, 1982; Frankfurt et al., 1990; Calizo and Flanagan-Cato, 2000), a classic estrogen target area of the brain for female sexual behavior (Pfaff, 1980).

\section{A. MECHANISM OF EXCITATORY SYNAPSE FORMATION IN THE HIPPOCAMPUS}

Estrogen treatment increases dendritic spine density on CA1 pyramidal neurons. As observed by electron microscopy, treatment of ovariectomized adult rats with estrogen also induces new synapses on spines and not on dendritic shafts of CA1 neurons (Woolley and McEwen, 1992). Estrogen did not effect dendritic length or branching (Gould et al., 1990; Woolley et al., 1990; Woolley and McEwen, 1992). Progesterone treatment acutely enhances spine formation. But, over a 12- to 24-hour period, progesterone caused the downregulation of estrogen-induced synapses (Gould et al., 1990; Woolley and McEwen, 1993).

Estrogens do not act alone and, in fact, ongoing excitatory neurotransmission is required for synapse induction, as shown by the finding that antagonists of NMDA receptors block estrogen-induced synaptogenesis on dendritic spines in ovariectomized female rats (Woolley and McEwen, 1994). Because estrogen treatment increases the density of NMDA receptors in the CA1 region of the hippocampus (Weiland, 1992; Woolley et al., 1997), the activation of NMDA receptors by glutamate is an essential factor in causing new excitatory synapses to develop.

Spines are occupied by asymmetric, excitatory synapses and are sites of $\mathrm{Ca}^{2+}$ ion accumulation and contain NMDA receptors (Horner, 1993). NMDA receptors are expressed in large amounts in CA1 pyramidal neurons and can be imaged by conventional immunocytochemistry as well as by confocal imaging, in which individual dendrites and spines can be studied for co-localization with other markers (Gazzaley et al., 1996). Confocal microscopic imaging showed that estrogen treatment upregulates immunoreactivity for the largest NMDA receptor subunit, NR1, on dendrites and cell bodies of CA1 pyramidal neurons, whereas NR1 mRNA levels did not change after estrogen treatment that induces new synapses (Gazzaley et al., 1996). This suggests the possibility that NR1 expression is regulated post-transcriptionally by estrogen.

Recent evidence indicates that in young female rats, estrogen induction of NR1 is proportional to the induction of new spines, so that NMDA receptor density per spine is not increased; however, in the aging female rat, there is NR1 induction without an increase in dendritic spines (Adams et al., 2001) (Figure 3). 


\section{YOUNG}

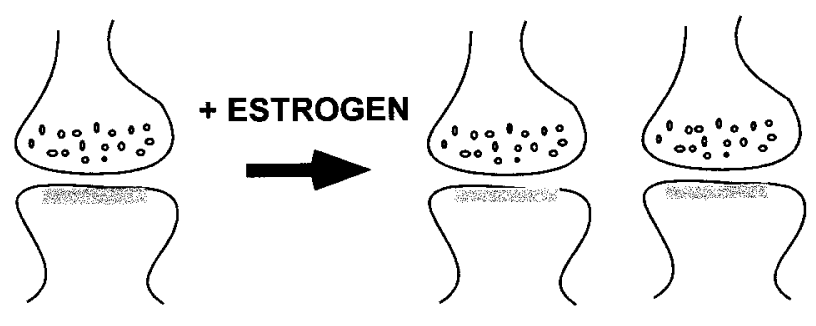

\section{AGED}

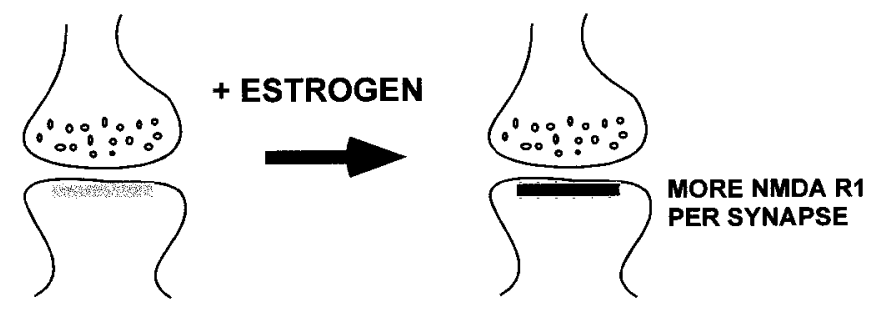

FIG. 3. Young adult female rats show upregulation of both NMDA receptors and dendritic spines on CA1 pyramidal neurons in hippocampus, with a proportional increase of NMDA receptors and spines. In contrast, the aging rat hippocampus responds to estrogen by upregulating NMDA receptor R1 subunit expression but not by increasing the number of spine synapses. [Redrawn from Adams MM, Shah RA, Janssen WGM, Morrison JH 2001 Different modes of hippocampal plasticity in response to estrogen in young and aged female rats. Proc Natl Acad Sci USA 98:8071-8076. Copyright 2001 National Academy of Sciences, USA.]

This might make the aging hippocampus more vulnerable to excitotoxic damage, for example, by stroke or seizures.

\section{B. CELLULAR AND MOLECULAR EVENTS ASSOCIATED WITH SYNAPSE FORMATION}

The estrogen-induced increase in dendritic spines on CA1 neurons parallels an increase in synapse density on spines without any decrease in shaft synapses (Woolley and McEwen, 1992), implying that new spine synapses are formed. Whereas synapse formation during development is considered to be a collaborative process involving in-growth of a presynaptic element on a site where a postsynaptic spine is either present or ready to form (Horner, 1993), the story for estrogen-regulated hippocampal synaptogenesis is somewhat different. Estrogens induce increased numbers of synapses on multiple synaptic boutons between neurons not previously connected (Yankova et al., 2001) (Figure 4). This is 

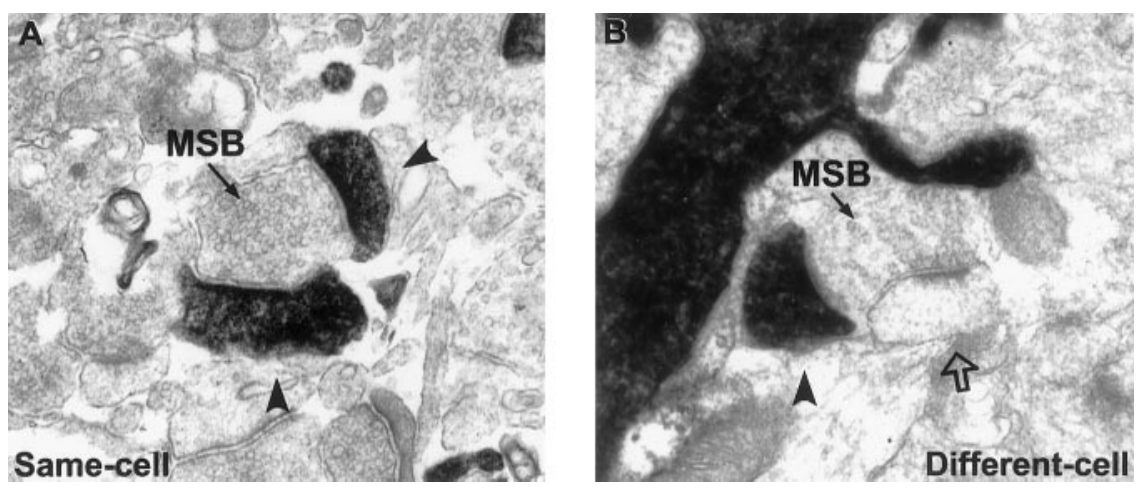

FIG. 4. Estrogen treatment of young adult female rats increases the number of dendritic spines on CA1 pyramidal neurons that are associated with multiple synaptic boutons (MSB), (i.e., more than one spine contacting a presynaptic terminal). Two examples are shown. On the left is a same cell bouton receiving two spines from the same cell that had been filled with dye to make it electron dense in the electron micrograph. On the right is a different cell bouton, where two different cells send spines to contact the same presynaptic terminal. Estrogen treatment increases preferentially the number of different cell MSBs. [Reprinted with permission from Yankova M, Hart SA, Woolley CS 2001 Estrogen increases synaptic connectivity between single presynaptic inputs and multiple postsynaptic CA1 pyramidal cells: a serial electron-microscopic study. Proc Natl Acad Sci USA 98:3525-3530. Copyright 2001 National Academy of Sciences, USA.]

reminiscent of the finding in cultured hippocampal cells studied by time-lapse photography that filopodia extend from dendrites and reach out to establish contact with nearby axons (Ziv and Smith, 1996). This implies an active role for the dendrite in forming synaptic contacts.

Gene products characterizing dendritic spines include spinophilin, a protein that helps to bundle actin filaments in the dendritic spine and regulates many of the properties of spines (Allen et al., 1997; Feng et al., 2000). As reviewed in McEwen et al. (2001), the calcium-calmodulin kinase II (CaMKII) is a major protein of the postsynaptic density that plays an important role in long-term potentiation (LTP) and synaptic differentiation. Recent evidence indicates that CaMKII plays a key role in the formation of synapses and localization of receptors in synapses. Glutamatergic synapses contain other key proteins in the postsynaptic density besides CaMKII; these include PSD-95, densin-180, and citron, a rac/rho effector protein. PSD-95 plays a key role in anchoring the NMDA receptor within the synapse. The NMDA R1 (NR1) receptor subunit is one of those proteins that may be translated from mRNA located in the dendrites (Gazzaley et al., 1997).

There are a number of presynaptic molecular markers of mature synapses that can be used in studies of synapse formation (McEwen et al., 2001). GAP43 is a marker of the growth cone and has been shown to increase in the 
hypothalamus after estrogen treatment; however, no studies of this type have been done on the hippocampus. SNAP-25 is a marker of synaptic vesicles, as are syntaxin, synaptotagmins, synaptoporin, synaptophysin, and the synapsins. Although mRNAs for these proteins are most likely found in neuron cell bodies, growth cones of hippocampal neurons in culture have been reported to have mRNAs for proteins such as GAP43 and Arc and perhaps other presynaptic proteins; these can be translated in the growth cone (Crino and Eberwine, 1996).

\section{APPLICATION OF RADIOIMMUNOCYTOCHEMISTRY TO STUDY SYNAPSE FORMATION AND MATURATION}

The methods used to assess synapse formation (i.e., Golgi staining, dye filling of cells, electron microscopy) are all labor intensive and time consuming and do not provide information about the underlying molecular events. Radioimmunocytochemistry is a method for assessing the locally expressed levels of synaptic and spine proteins using a primary antibody and a radioactive secondary antibody, then assessing levels of radioactivity using quantitative autoradiography. This procedure has not only confirmed the anatomical methods for assessing spine synapse formation but has also added a new dimension by providing insights into estrogen-induced increases in proteins that characterize presynaptic terminals and spines.

Figure 5 shows the results of the first study, using synaptophysin and syntaxin as presynaptic markers and spinophilin as a spine marker (Brake et al., 2001). Estrogen treatment was conducted exactly as in previous studies using the Golgi method and the estrogen antagonist, CI 628, was used to block estrogen actions (McEwen et al., 1999a). Estrogen treatment induced both pre- and postsynaptic markers in the stratum oriens and stratum radiatum of the CA1 region, location of the spine synapses (Brake et al., 2001). The magnitude of the increases corresponded very well to the magnitude of the changes in spine density seen with the Golgi method (Woolley et al., 1997; McEwen et al., 1999a). These effects were blocked by CI-628, which had no agonist effects by itself, and this finding agreed with the Golgi results (McEwen et al., 1999a). One unique finding with radioimmunocytochemistry is the estrogen-induced increase in spinophilin immunoreactivity in the hilus of the dentate gyrus and in the stratum lucidum of CA3, neither of which is accompanied by increases in the presynaptic markers, synaptophysin, and syntaxin (Brake et al., 2001). This suggests that there may be a process of synapse maturation taking place that reflects expression of spinophilin in the absence of any estrogen-induced changes in presynaptic proteins. Further studies are needed to confirm this interpretation.

\section{CELL NUCLEAR ESTROGEN RECEPTORS IN THE HIPPOCAMPUS}

Adult CA1 pyramidal cells of the dorsal hippocampus do not express detectable cell nuclear ER by tritium autoradiography and light microscopic 


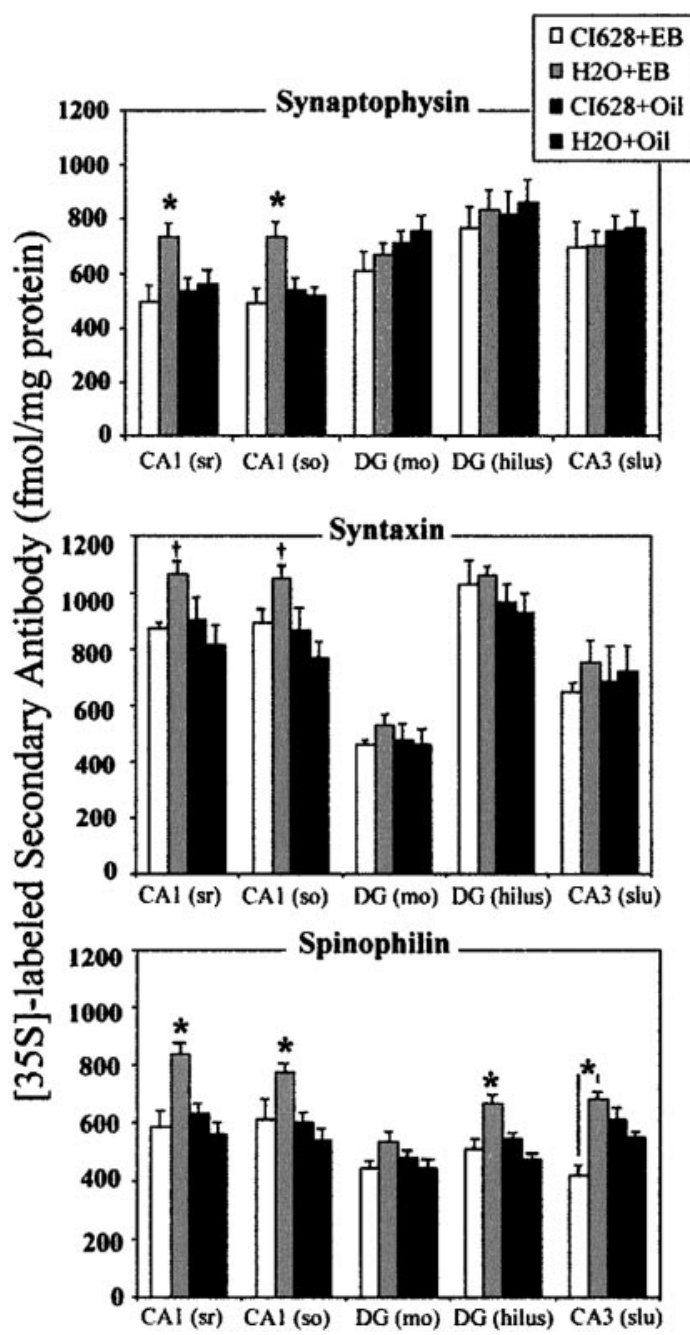

FIG. 5. Radioimmunocytochemistry for two presynaptic (synaptophysin and syntaxin) and one spine-specific (spinophilin) marker reveals the same magnitude of up-regulation by estrogen treatment as has been shown by morphological techniques for dendritic spines on CA1 neurons of the female rat hippocampus. ${ }^{35}$ S-labeled secondary antibody was used for quantitative autoradiography of the distribution and intensity of labeling of synaptic proteins by specific primary antibodies. Treatment with the nonsteroidal estrogen antagonist, CI 628, blocks the estrogen effect and does not produce an agonist-like effect of its own. These findings are very similar to a study using the Golgi method to reveal dendritic spines (McEwen et al., 1999a). [Reprinted with permission from Brake WG, Alves SE, Dunlop JC, Lee SJ, Bulloch K, Allen PB, Greengard P, McEwen BS 2001 Novel target sites for estrogen action in the dorsal hippocampus: an examination of synaptic proteins. Endocrinology 142:1284-1289. Copyright The Endocrine Society.] 
immunocytochemistry (Weiland et al., 1997), whereas they express low levels of $\mathrm{ER} \alpha$ and $\mathrm{ER} \beta$ mRNA by in situ hybridization (Shughrue and Merchenthaler, 2000; McEwen et al., 2001). Instead, immunocytochemistry for ER $\alpha$ showed cell nuclear ER in sparsely distributed interneurons in the CA1 region as well as other regions of Ammon's horn and dentate gyrus, with greater density in the ventral than dorsal hippocampus (McEwen and Alves, 1999). As far as ER $\beta$ immunoreactivity, an antibody generated at the C-terminal end of the receptor revealed only weak labeling of cell nuclei, particularly in the ventral hippocampus, and some staining of dendrites of pyramidal cells (Shughrue and Merchenthaler, 2001).

Autoradiography with ${ }^{125}$ I estrogen to label ER with a higher-specific radioactivity showed binding sites not previously detected in hippocampus using ${ }^{3} \mathrm{H}$ estradiol (Shughrue and Merchenthaler, 2000). Besides the interneurons previously seen to contain ER $\alpha$ by other methods, labeling with ${ }^{125} \mathrm{I}$ estrogen was found in CA1-CA3 pyramidal cell nuclei in ventral hippocampus. A similar dorsal-to-ventral gradient was seen for ER $\alpha$ and ER $\beta$ mRNA and ${ }^{125}$ I estrogen binding. The ER $\alpha$ signal appeared to be stronger than that for $\operatorname{ER} \beta$ (Shughrue and Merchenthaler, 2000). Thus, the greater sensitivity of ${ }^{125}$ I estrogen labeling of ER reveals sites that may indicate locations of estrogen actions in hippocampal pyramidal cells, particularly in the ventral hippocampus. A recent developmental study of $\mathrm{ER} \alpha$ in the rat hippocampus is consistent with this and suggests that, early in development, more pyramidal cells may have nuclear ER $\alpha$ than in the adult (Solum and Handa, 2001). Recent data with radioimmunocytochemistry have shown much stronger estrogen effects on synapse and spine protein levels in ventral, compared to dorsal hippocampus (Bulloch et al., 2000).

\section{E. CELL-CULTURE MODEL OF SYNAPSE FORMATION}

It has been possible to study estrogen-induced synapse formation in cell cultures of hippocampal neurons. In this model, estrogen induces spines on dendrites of dissociated hippocampal neurons in cell culture by a process that is blocked by an NMDA receptor antagonist and not by an AMPA (alpha-amino3-hydroxy-5-methylisoxasole proprionic acid)/kainate receptor blocker (Murphy and Segal, 1996). Furthermore, estrogen treatment was found to increase expression of phosphorylated cyclic AMP response binding protein (CREB). A specific antisense to CREB prevented both the formation of dendritic spines and the elevation in phosphoCREB immunoreactivity (IR) (Murphy and Segal, 1997).

The cellular location of $\mathrm{ER} \alpha$ in the cultures, resembling the in vivo localization, was in putative inhibitory interneurons (i.e., glutamic acid decarboxylase (GAD)-immunoreactive cells) that constituted around $20 \%$ of total neuronal population. Estrogen treatment caused decreases in GAD content and the number of neurons expressing GAD. Mimicking this decrease with an 
inhibitor of gamma aminobutyric acid (GABA) synthesis, mercaptopropionic acid, caused an upregulation of dendritic spine density, paralleling the effects of estrogen (Murphy et al., 1998a). Thus, estrogen-induced synapse formation may involve the suppression of GABA inhibitory input to the pyramidal neurons where the synapses are being generated (Figure 6).

An additional factor in the formation of dendritic spines in the in vitro cell culture model is the neurotrophin, brain-derived neurotrophic factor (BDNF) (Murphy et al., 1998b). Besides downregulating GABA expression in inhibitory interneurons, estrogen treatment also reduced BDNF by $60 \%$ within 24 hours (Murphy et al., 1998b). Exogenous BDNF blocked estrogen induction of dendritic spines; furthermore, BDNF depletion either with an antisense or blockade with BDNF antibodies mimicked estrogen in inducing spine density. Thus, $\mathrm{BDNF}$ is also an important player in regulating dendritic spines in hippocampal neurons (Murphy et al., 1998b). In this connection, neurotrophins such as BDNF and neurotrophin-3 (NT-3) also increase the function of inhibitory and excitatory

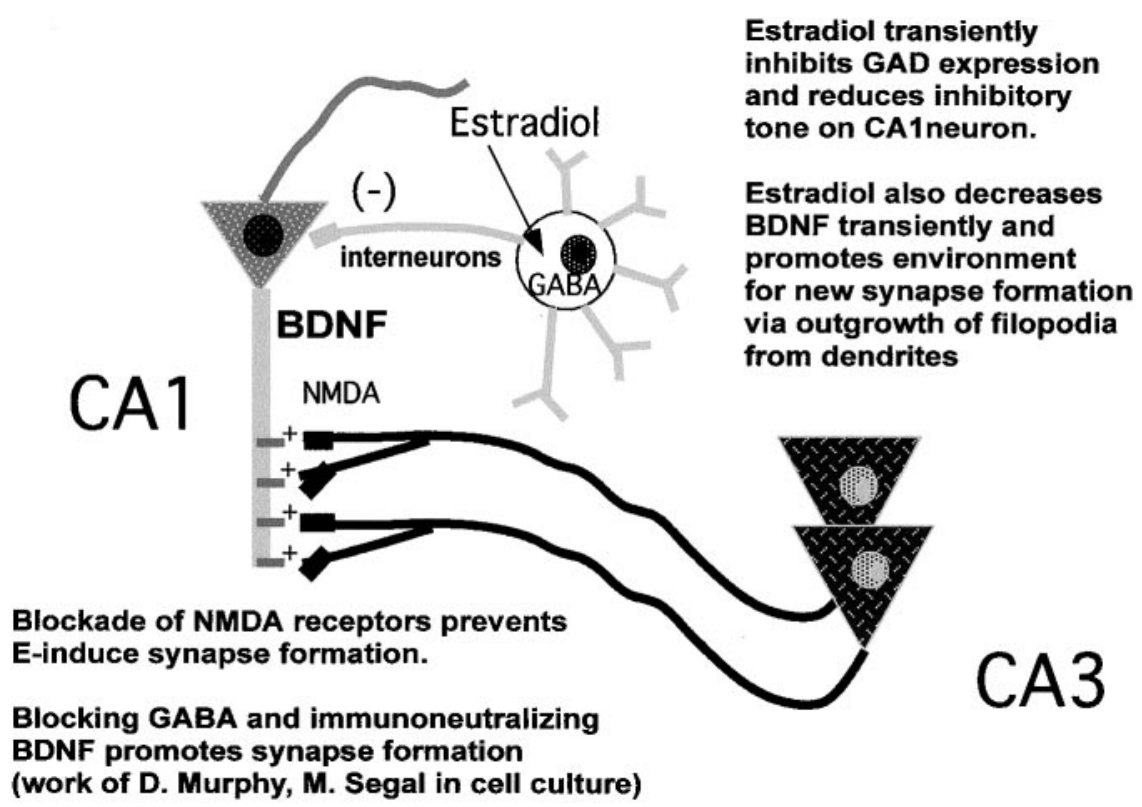

Fig. 6. Because of the prominent presence of $\mathrm{ER} \alpha$ in some of the inhibitory interneurons in the hippocampus and the presence of similar ER $\alpha$-positive GABA cells in hippocampal cell culture, Murphy and Segal proposed a model of the control of spine synapse formation in which estrogen treatment suppresses the inhibitory tone upon CA1 pyramidal neurons and creates an environment conducive to the formation of new excitatory spine synapses. Blocking GABA inhibition and immunoneutralizing the neurotrophin, BDNF increased spine synapse formation in cell culture. [See text for details and references.] 
synapses in hippocampal cell cultures; moreover, BDNF causes an increase in axonal branching and length of GABAergic interneurons (Vicario-Abejon et al., 1998). Hence, BDNF appears to favor the growth of inhibitory interneurons and the functional activation of synaptic transmission in excitatory and inhibitory cells, while suppressing the formation of the type of excitatory synaptic connections induced by estradiol (Figure 6).

\section{F. NON-NUCLEAR ESTROGEN RECEPTORS}

As compelling as the role of estrogen-regulated GABA input appears to be to the mechanism of synapse formation, we were not satisfied that there was no additional role for estrogen actions in the pyramidal neurons themselves. Given the increasing evidence for such a mechanism, it seemed plausible that, besides the indirect, trans-synaptic mechanism described above, local signaling by estrogen might be involved. This hypothesis was stimulated by a seminal study that $\operatorname{ER} \alpha$ and $\operatorname{ER} \beta$ into Chinese hamster ovarian cells found that both ERs are expressed in a form that couples to second messenger systems that are stimulated by estrogen and blocked at least partially by nonsteroidal estrogen antagonists (Razandi et al., 1999). Previous studies had indicated that non-nuclear ERs can be seen at the light microscopic level in cultured cells (Clarke et al., 2000) and also at the electron microscopic (EM) level in hypothalamus (Blaustein et al., 1992). The proliferation of articles on non-nuclear actions of estrogen via membrane ER and membrane-associated ER (Kelly and Levin, 2001) has reinforced the importance of investigating non-nuclear actions of estrogens in the hippocampus.

Electron microscopy was used to examine ER $\alpha$ localization in rat hippocampal formation (Milner et al., 2001) utilizing four antibodies to different parts of the $\operatorname{ER} \alpha$ structure, two polyclonal and two monoclonal. The specificity of these antibodies was determined by preabsorption with the full-length ER protein, which abolished labeling in all sites examined, both nuclear and non-nuclear. We were able to see at the EM level the cell nuclear labeling seen by light microscopy in some GABA interneurons. In addition, some pyramidal and granule neuron perikarya have small amounts of $\operatorname{ER} \alpha$ IR in the nuclear membrane, which is consistent with a recent report that ${ }^{125} \mathrm{I}$ estradiol labels a small number of estrogen-binding sites in cell nuclei of hippocampal principal cells (Shughrue and Merchenthaler, 2000).

In stratum radiatum of CA1, around $50 \%$ of the ER $\alpha$-IR profiles were found in unmyelinated axons and axon terminals containing small synaptic vesicles. This is of potential functional relevance, given findings that estrogen can influence neurotransmitter release (see McEwen et al., 2001, for references). The synaptic $\operatorname{ER} \alpha$-IR was found in terminals that formed both asymmetric and symmetric synapses on dendritic shafts and spines, suggesting that both excita- 
tory and inhibitory transmitter systems are associated with $\mathrm{ER} \alpha$ (Milner et al., 2001).

Around $25 \%$ of the ER $\alpha$ IR was found in dendritic spines of principal cells, where it often was associated with spine apparati and/or post-synaptic densities, suggesting that estrogen might act locally to regulate calcium availability, phosphorylation, or protein synthesis. Finally, the remaining $25 \%$ of ER $\alpha$ IR was found in astrocytic profiles, often located near the spines of principal cells.

While these findings corroborate existing evidence for an indirect GABAergic mediation of estrogen actions (Murphy et al., 1998a; Rudick and Woolley, 2000), the close association between the $\operatorname{ER} \alpha$-IR and dendritic spines supports a possible local, nongenomic role for this ER in regulation of dendritic spine density via second messenger systems. Initial in vivo and in vitro studies in hippocampus of one second messenger pathway, the phosphorylation of CREB, have indicated that estrogen has rapid effects that are evident within as little as 15 minutes to increase phosphoCREB immunoreactivity in cell nuclei of hippocampal pyramidal neurons (S. Lee, S. Alves, B. McEwen, unpublished data). One pathway by which CREB phosphorylation may occur involves the phosphoinositol-3 (PI3) kinase, or Akt, system (Datta et al., 1999). Studies are underway to try to connect these events together in the early actions of estrogen on hippocampal neurons that precede the induction of synapse formation. We next consider some of the cellular and molecular events associated with the formation of synapses in which estrogen actions may be involved.

\section{G. DENDRITIC MRNA TRANSPORT AND PROTEIN SYNTHESIS}

The finding of non-nuclear $\mathrm{ER} \alpha$ in dendritic spines compelled us to consider sites and mechanisms whereby estrogens could regulate the process of synapse formation via post-transcriptional mechanisms. Protein synthesis is likely to be an essential component of de novo synapse formation. Neurons have at least three strategies for activity-dependent regulation of protein synthesis and targeting of those proteins to pre- and postsynaptic sites (Tiedge et al., 2001). First, there is translation of mRNA in the cell soma and trafficking of proteins to "tagged" synapses. Second is transport of mRNA into the dendrites or growth cones and local translation into protein on polyribosomal clusters such as are found at the base of spines. The third strategy is local regulation of the translation of transported mRNAs (Tiedge et al., 2001).

Dendrites contain transported mRNAs for gene products such as MAP-2, CaMKII, NMDA R1 subunit, Arc, GAP-43, and BC1 (Gao, 1998). One feature of the regulation of translation is that the dendritic mRNAs are deficient in poly A; therefore, the regulation of polyadenylation by cytoplasmic polyadenylation element binding protein (CPEP) is able to rapidly activate translation (Wells et al., 2000). Moreover, other regulatory points such as the initiation of the 
translation process via regulatory factors are subject to second messengerstimulated phosphorylation (Gingras et al., 1999). These are currently under investigation in our laboratory as far as possible regulation by estrogen.

\section{H. A MODEL OF ESTROGEN ACTION INVOLVING GENOMIC AND NONGENOMIC ERs}

The results summarized above have led us to propose a testable, working model (Figure 7) that delineates possible sites of estrogen action in relation to the location of nuclear and non-nuclear ERs. Although this model pertains to ER $\alpha$ because we know more about its distribution, further studies of ER $\beta$ may reveal that it is present in non-nuclear as well as cell nuclear sites within the hippocampus and may participate in some of the processes outlined in Figure 7. According to our model, ER in the dendritic spine may be associated with the activation of mRNA translation from polyribosomes (Tiedge et al., 2001) or endomembrane structures found in spines (Pierce et al., 2000). In addition, other second messenger signaling effects might include the phosphorylation of neurotransmitter receptors or ion channels. ERs in certain presynaptic terminals might modulate neurotransmitter release or reuptake (see McEwen et al., 2001, for references). Moreover, ER-mediated activation of second messenger systems in dendritic spines and presynaptic endings might lead to retrograde signal transduction back to the cell nucleus, perhaps via Akt or CREB, providing another pathway through which estrogen could regulate gene expression. As indicated at the bottom right of Figure 7, we consider that these postulated actions of estrogen operate synergistically with the actions of estrogen via nuclear receptors in interneurons that modulate the inhibitory tone upon the CA1 pyramidal neurons where synapse formation occurs.

\section{Possible Functional Significance}

The functional significance of estrogen actions in the hippocampal CA1 region is evident from electrophysiological studies indicating that estrogen treatment of ovariectomized rats produces a delayed facilitation of synaptic transmission in CA1 neurons that is NMDA mediated and leads to an enhancement of voltage-gated $\mathrm{Ca}^{2+}$ currents (Wong and Moss, 1992). Using biocytin injection after recording from CA1 pyramidal neurons in order to visualize estrogen induction of dendritic spines, Woolley and coworkers (1997) found that spine density correlated negatively with input resistance. Input/output curves showed an increased slope under conditions where NMDA receptor-mediated currents predominated, whereas there was no increased slope where AMPA receptor currents predominated. Other studies have shown that LTP sensitivity peaks on the afternoon of proestrus in intact female rats at exactly the time when 


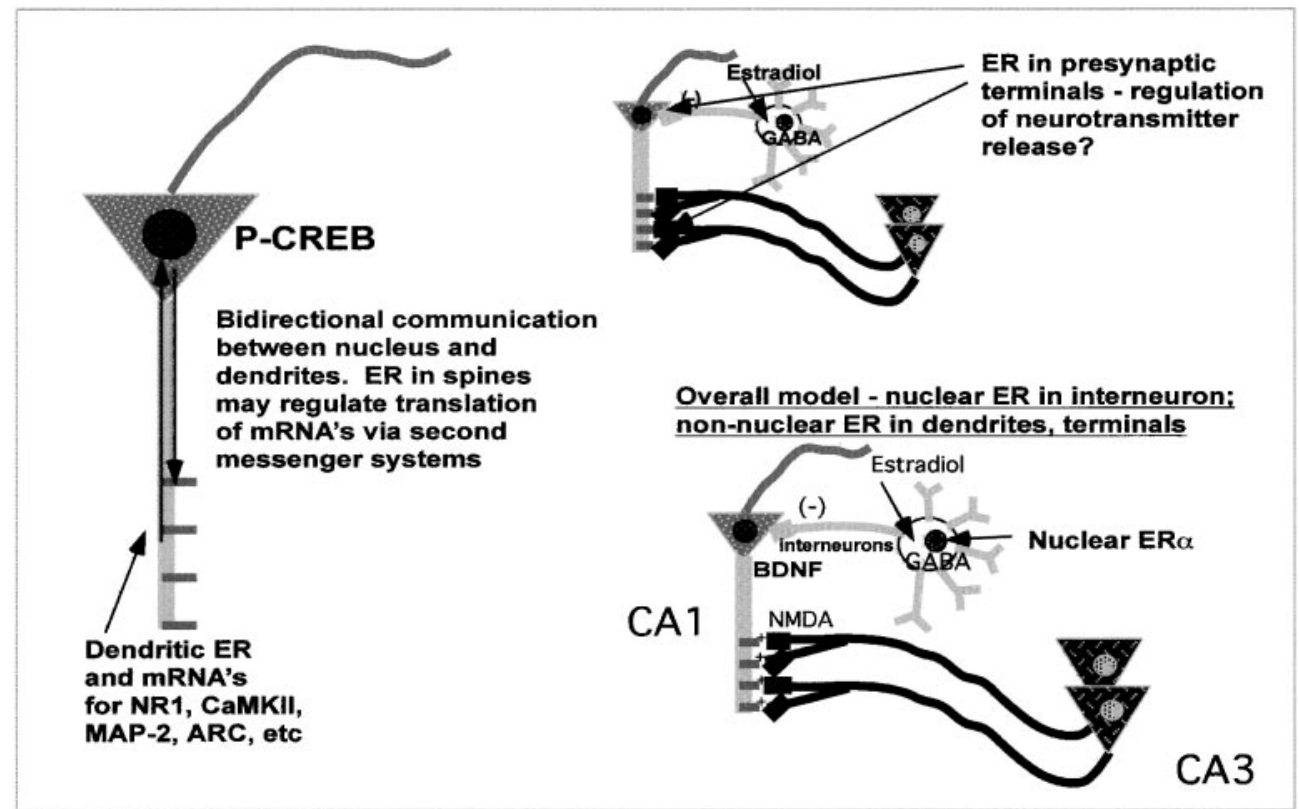

FIG. 7. Schematic depiction of an overall model of estrogen (E) regulation of spine synapse formation, based upon the model shown in Figure 6, combined with ER localization in non-nuclear sites in CA1 pyramidal neurons that respond to E with synapse formation. As summarized in the text, ER $\alpha$ immunoreactivity is found in dendrites, presynaptic terminals, glia, and the nuclear envelope of some principal cells as well as in cell nuclei of inhibitory interneurons (Milner et al., 2001). Glia may be involved in synapse formation and/or removal. The left side of the figure highlights the fact that dendrites are sites of protein synthesis on polyribosomes and at endomembrane structures using RNAs transported from the cell body (see text). Non-nuclear ER may be involved in other E effects linked to second messenger activation on processes such as neurotransmitter release (top of figure) and phosphorylation of neurotransmitter receptors and ion channels. Second messenger activation by E in nerve terminals, dendrites, and glial cell processes may result in retrograde second messenger signals, such as P-CREB and P-Akt, that return to signal the genome. These actions synergize with the transient decrease in GABA-inhibitory tone produced by estrogen actions on ER $\alpha$-containing inhibitory interneurons based upon the model in Figure 6. 
excitatory synapse density has reached its peak (Warren et al., 1995). Proestrus is also the time of the estrous cycle when seizure thresholds in dorsal hippocampus are the lowest (Terasawa and Timiras, 1968).

Besides affecting neuronal activity in hippocampus, estrogen treatment affects hippocampal-dependent learning and memory. In the natural estrous cycle of the female rat, a recent study has utilized a delayed matching-to-place task in female rats to show a close parallel between the temporal conditions by which estrogen improves memory and the conditions for it to induce new excitatory synaptic connections in the hippocampus (McEwen et al., 2001). Moreover, estrogen treatment of ovariectomized female rats has been reported to improve acquisition on a radial maze task as well as in a reinforced T-maze alternation task (Fader et al., 1998; Daniel et al., 1999). Furthermore, sustained treatment is reported to improve performance in a working memory task (O'Neal et al., 1996) as well as in the radial-arm maze (Luine et al., 1998; Daniel et al., 1999). Finally, the effects of estrogen replacement in rats are reminiscent of the effects of treatment in women whose estrogen levels have been suppressed by a gonadotrophin-releasing hormone agonist used to shrink the size of fibroids prior to surgery (Sherwin and Tulandi, 1996).

In addition to the delayed effects of estrogens in hippocampus, estrogens and some form of ER are involved in local signaling within neurons. Among the possible targets of local signaling is the translation of RNAs found in dendrites of hippocampal and other neurons. There are at least three other targets for local signaling by estrogens. They are 1) the rapid activation of kainate-induced ion currents via a $\mathrm{G}$ protein-coupled ER that is present in $\alpha$ ERKO mice and is insensitive to nonsteroidal estrogen antagonists (Gu et al., 1999); 2) the suppression of calcium ion currents that is mimicked by a nonsteroidal estrogen antagonist (Mermelstein et al., 1996); and 3) rapid actions of estradiol on NMDA receptor activity and LTP (Teyler et al., 1980; Foy et al., 1999).

\section{Conclusions}

It is abundantly clear that estrogen actions in brain and other tissues involve an array of cellular and molecular mechanisms and that estrogens influence many behavioral and physiological processes that go beyond their traditional role in reproduction. Brain regions such as the hippocampus are affected by estrogens, even though they have a paucity of cell nuclear ERs. These actions may be explained by the powerful trans-synaptic influence of a small number of ERcontaining cells upon other neurons (e.g., GABA inhibitory neurons depicted in Figure 6) or by non-nuclear ERs and second messenger activation, or a combination of both. Elsewhere in the nervous system, cell nuclear ER $\beta$ may well help explain estrogen actions in other brain areas that do not express ER $\alpha$. What all of this means is that, besides the classical genomic actions of estradiol that have 
been studied for over 40 years, the molecular mechanisms of estrogen action are likely to involve many pathways not ordinarily considered, in which indirect genomic activation may occur as a consequence of second messenger activation.

\section{REFERENCES}

Adams MM, Shah RA, Janssen WGM, Morrison JH 2001 Different modes of hippocampal plasticity in response to estrogen in young and aged female rats. Proc Natl Acad Sci USA 98:8071-8076

Allen PB, Ouimet CC, Greengard P 1997 Spinophilin, a novel protein phosphatase 1 binding protein localized to dendritic spines. Proc Natl Acad Sci USA 94:9956-9961

Alves S, Weiland NG, Hayashi S, McEwen B 1998 Immunocytochemical localization of nuclear estrogen receptors and progestin receptors within the dorsal raphe nucleus. J Comp Neurol 391:322-334

Alves SE, McEwen BS, Hayashi S, Korach KS, Pfaff DW, Ogawa S 2000 Estrogen-regulated progestin receptors are found in the midbrain raphe but not hippocampus of estrogen receptor alpha (ER $\alpha$ ) gene-disrupted mice. J Comp Neurol 427:185-195

Auger AP, Tetel MJ, McCarthy MM 2000 Steroid receptor coactivator-1 (SRC-1) mediates the development of sex-specific brain morphology and behavior. Proc Natl Acad Sci USA 97:7551-7555

Bazzett TJ, Becker JB 1994 Sex differences in the rapid and acute effects of estrogen on striatal D dopamine receptor binding. Brain Res 637:163-172

Bethea CL, Pecins-Thompson M, Schutzer WE, Gundlah CLZN 1999 Ovarian steroids and serotonin neural function. Mol Neurobiol 18:87-123

Blaustein JD, Lehman MN, Turcotte JC, Greene G 1992 Estrogen receptors in dendrites and axon terminals in guinea pig hypothalamus. Endocrinology 131:281-290

Brake WG, Alves SE, Dunlop JC, Lee SJ, Bulloch K, Allen PB, Greengard P, McEwen BS 2001 Novel target sites for estrogen action in the dorsal hippocampus: an examination of synaptic proteins. Endocrinology 142:1284-1289

Brinton RD 2001 Cellular and molecular mechanisms of estrogen regulation of memory function and neuroprotection against Alzheimer's disease: Recent insights and remaining challenges. Learn Memory 8:121-133

Bulloch K, Brake WG, Lee SJ, Patel A, Wolf OT, McEwen BS 2000 Estrogen increases synaptic protein immunoreactivity in the dorsal and ventral hippocampus of ovariectomized rats. Abstr Soc Neurosci 26(7.1):4 (Abstract)

Calizo LH, Flanagan-Cato LM 2000 Estrogen selectively regulates spine density within the dendritic arbor of rat ventromedial hypothalamic neurons. J Neurosci 20:1589-1596

Carrer H, Aoki A 1982 Ultrastructural changes in the hypothalamic ventromedial nucleus of ovariectomized rats after estrogen treatment. Brain Res 240:221-233

Clarke CH, Norfleet AM, Clarke MSF, Watson CS, Cunningham KA, Thomas ML 2000 Perimembrane localization of the estrogen receptor $\alpha$ protein in neuronal processes of cultured hippocampal neurons. Neuroendocrinology 71:34-42

Crino PB, Eberwine J 1996 Molecular characterization of the dendritic growth cone: regulated mRNA transport and local protein synthesis. Neuron 17:1173-1187

Daniel JM, Roberts SL, Dohanich GP 1999 Effects of ovarian hormones and environment on radial maze and water maze performance of female rats. Physiol Behav 66:11-20

Datta SR, Brunet A, Greenberg ME 1999 Cellular survival: a play in three Akts. Genes Dev 13:2905-2927

Eichenbaum H, Otto T 1992 The hippocampus - what does it do? Behav Neural Biol 57:2-36 
Fader AJ, Hendricson AW, Dohanich GP 1998 Estrogen improves performance of reinforced T-maze alternation and prevents the amnestic effects of scopolamine administered systemically or intrahippocampally. Neurobiol Learn Memory 69:225-240

Feng J, Yan Z, Ferreira A, Tomizawa K, Liauw JA, Zhuo M, Allen PB, Ouimet CC, Greengard P 2000 Spinophilin regulates the formation and function of dendritic spines. Proc Natl Acad Sci USA 97:9287-9292

Fischette C, Biegon A, McEwen BS 1984 Sex steroid modulation of the serotonin behavioral syndrome. Life Sci 35:1197-1206

Foy MR, Xu J, Xie X, Brinton RD, Thompson RF, Berger TW $199917 \beta$-estradiol enhances NMDA receptor-mediated EPSPs and long-term potentiation. J Neurophysiol 81:925-929

Frankfurt M, Gould E, Wolley C, McEwen BS 1990 Gonadal steroids modify dendritic spine density in ventromedial hypothalamic neurons: a Golgi study in the adult rat. Neuroendocrinology 51:530-535

Gao F-B 1998 Messenger RNAs in dendrites: localization, stability, and implications for neuronal function. BioEssays 20:70-78

Gazzaley AH, Weiland NG, McEwen BS, Morrison JH 1996 Differential regulation of NMDAR1 mRNA and protein by estradiol in the rat hippocampus. J Neurosci 16:6830-6838.

Gazzaley AH, Benson DL, Huntley GW, Morrison JH 1997 Differential subcellular regulation of NMDAR1protein and mRNA in dendrites of dentate gyrus granule cells after perforant path transection. J Neurosci 17:2006-2017

Gingras A-C, Raught B, Sonenberg N 1999 eIF4 initiation factors: Effectors of mRNA recruitment to ribosomes and regulators of translation. Annu Rev Biochem 68:913-963

Gould E, Woolley C, Frankfurt M, McEwen BS 1990 Gonadal steroids regulate dendritic spine density in hippocampal pyramidal cells in adulthood. J Neurosci 10:1286-1291

Goy R, McEwen BS 1980 Sexual Differentiation of the Brain. Cambridge: MIT Press

Green PS, Bishop J, Simpkins JW 1997 17 $\beta$-Estradiol exerts neuroprotective effects on SK-N-SH cells. J Neurosci 17:511-515

Gu Q, Korach KS, Moss RL 1999 Rapid action of 17 $\beta$-estradiol on kainate-induced currents in hippocampal neurons lacking intracellular estrogen receptors. Endocrinology 140:660-666

Gundlah C, Pecins-Thompson M, Schutzer WE, Bethea CL 1999 Ovarian steroid effects on serotonin $1 \mathrm{~A}, 2 \mathrm{~A}$ and $2 \mathrm{C}$ receptor mRNA in macaque hypothalamus. Mol Brain Res 63:325-339

Higley JD, Linnoila M 1997 Low central nervous system serotonergic activity is traitlike and correlates with impulsive behavior. Ann NY Acad Sci 836:39-56

Horner CH 1993 Plasticity of the dendritic spine. Progr Neurobiol 41:281-321

Hrabovszky E, Kallo I, Hajszan T, Shughrue PJ, Merchenthaler I, Liposits Z 1998 Expression of estrogen receptor- $\beta$ messenger ribonucleic acid in oxytocin and vasopressin neurons of the rat supraoptic and paraventricular nuclei. Endocrinology 139:2600-2604

Jacobs BL 1994 Serotonin, motor activity and depression-related disorders. Am Sci 82:456-463

Jacobson L, Sapolsky R 1991 The role of the hippocampus in feedback regulation of the hypothalamic-pituitary-adrenocortical axis. Endocr Rev 12:118-134

Jensen E, Jacobson H 1962 Basic guides to the mechanism of estrogen action. Rec Progr Horm Res 18:387-408

Kelly MJ, Levin ER 2001 Rapid actions of plasma membrane estrogen receptors. Trends Endocrinol Metab 12:152-156

Kelly MJ, Wagner EJ 1999 Estrogen modulation of G-protein-coupled receptors. Trends Endocrinol Metab 10:369-374

Kelly M, Moss R, Dudley C 1977 The effects of microelectrophoretically applied estrogen, cortisol and acetylcholine on medial preoptic-septal unit activity throughout the estrous cycle of the female rat. Exp Brain Res 30:53-64 
Kimura D 1992 Sex differences in the brain. Sci Am 267:119-125

Kuiper GGJM, Carlsson B, Grandien K, Enmark E, Haggblad J, Nilsson S, Gustafsson J-A 1997 Comparison of the ligand binding specificity and transcript tissue distribution of estrogen receptors $\alpha$ and $\beta$. Endocrinology 138:863-870

Kuiper GGJM, Shughrue PJ, Merchenthaler I, Gustafsson J-A 1998 The estrogen receptor $\beta$ subtype: a novel mediator of estrogen action in neuroendocrine systems. Front Neuroendocrinol 19:253-286

Lee SJ, McEwen BS 2001 Neurotrophic and neuroprotective actions of estrogens and their therapeutic implications. Annu Rev Pharmacol Toxicol 41:569-591

Luine V, McEwen BS 1977 Effects of an estrogen antagonist on enzyme activities and 3H estradiol nuclear binding in uterus, pituitary and brain. Endocrinology 100:903-910

Luine VN, Richards ST, Wu VY, Beck KD 1998 Estradiol enhances learning and memory in a spatial memory task and effects levels of monoaminergic neurotransmitters. Horm Behav 34:149-162

Maruyama K, Endoh H, Sasaki-Iwaoka H, Kanou H, Shimaya E, Hashimoto S, Kato S, Kawashima H 1998 A novel isoform of rat estrogen receptor beta with 18 amino acid insertion in the ligand binding domain as a putative dominant negative regular of estrogen action. Biochem Biophys Res Commun 246:142-147

Mattson MP, Robinson N, Guo Q 1997 Estrogens stabilize mitochondrial function and protect neural cells against the pro-apoptotic action of mutant presenilin-1. NeuroReport 8:38173821

Maus M, Homburger V, Bockaert J, Glowinski J, Premont J 1990 Pretreatment of mouse striatal neurons in primary culture with $17 \beta$-estradiol enhances the pertussis toxin-catalyzed ADPribosylation of $\mathrm{G} \alpha_{\mathrm{o}, \mathrm{i}}$ protein subunits. J Neurochem 55:1244-1251

McEwen BS 1983 Gonadal steroid influences on brain development and sexual differentiation. In: Greep R, ed. Reproductive Physiology IV. University Park, MD: University Park Press; $99-145$

McEwen BS, Alves SH 1999 Estrogen actions in the central nervous system. Endocr Rev 20:279_ 307

McEwen BS, Tanapat P, Weiland NG 1999a Inhibition of dendritic spine induction on hippocampal CA1 pyramidal neurons by a non-steroidal estrogen antagonist in female rats. Endocrinology 140:1044-1047

McEwen BS, Tanapat P, Weiland NG 1999b Inhibition of dendritic spine induction on hippocampal CA1 pyramidal neurons by a nonsteroidal estrogen antagonist in female rats. Endocrinology 140:1044-1047

McEwen BS, Akama K, Alves S, Brake WG, Bulloch K, Lee S, Li C, Yuen G, Milner TA 2001 Tracking the estrogen receptor in neurons: Implications for estrogen-induced synapse formation. Proc Natl Acad Sci USA 98:7093-7100

Meisel R, Dohanich G, McEwen BS, Pfaff DW 1987 Antagonism of sexual behavior in female rats by ventromedial hypothalamic implants of antiestrogen. Neuroendocrinology 45:201-207

Mermelstein PG, Becker JB, Surmeier DJ 1996 Estradiol reduces calcium currents in rat neostriatal neurons via a membrane receptor. J Neurosci 16:595-604

Milner TA, McEwen BS, Hayashi S, Li CJ, Reagen L, Alves SE 2001 Ultrastructural evidence that hippocampal alpha estrogen receptors are located at extranuclear sites. J Comp Neurol 429:355-371

Mize AL, Poisner AM, Alper RH 2001 Estrogens act in rat hippocampus and frontal cortex to produce rapid, receptor-mediated decreases in serotonin $5-\mathrm{HT}_{1 \mathrm{~A}}$ receptor function. Neuroendocrinology 73:166-174

Murphy DD, Segal M 1996 Regulation of dendritic spine density in cultured rat hippocampal neurons by steroid hormones. J Neurosci 16:4059-4068 
Murphy DD, Segal M 1997 Morphological plasticity of dendritic spines in central neurons is mediated by activation of cAMP response element binding protein. Proc Natl Acad Sci USA 94:1482-1487

Murphy DD, Cole NB, Greenberger V, Segal M 1998a Estradiol increases dendritic spine density by reducing GABA neurotransmission in hippocampal neurons. J Neurosci 18:2550-2559

Murphy DD, Cole NB, Segal M 1998b Brain-derived neurotrophic factor mediates estradiol-induced dendritic spine formation in hippocampal neurons. Proc Natl Acad Sci USA 95:11412-11417

Nabekura J, Oomura Y, Minami T, Mizuno Y, Fukuda A 1986 Mechanism of the rapid effect of $17 \beta$-estradiol on medial amygdala neurons. Science 233:226-228

Naftolin F 1994 Brain aromatization of androgens. J Reprod Med 39:257-261

O'Neal MF, Means LW, Poole MC, Hamm RJ 1996 Estrogen affects performance of ovariectomized rats in a two-choice water-escape working memory task. Psychoneuroendocrinology 21:51-65

Osterlund MK, Overstreet DH, Hurd YL 1999 The flinders sensitive line rats, a genetic model of depression, show abnormal serotonin receptor mRNA expression in the brain that is reversed by $17 \beta$-estradiol. Mol Brain Res 74:158-166

Osterlund MK, Halldin C, Hurd YL 2000 Effects of chronic 17 $\beta$-estradiol treatment on the serotonin 5- $\mathrm{HT}_{1 \mathrm{~A}}$ receptor mRNA and binding levels in the rat brain. Synapse 35:39-44

Paech K, Webb P, Kuiper GGJM, Nilsson S, Gustafsson J-A, Kushner PJ, Scanlan TS 1997 Differential ligand activation of estrogen receptors ER $\alpha$ and ER $\beta$ at AP1 sites. Science 277:1508-1510

Pettersson K, Grandien K, Kuiper GGJM, Gustafsson J-A 1997 Mouse estrogen receptor $\beta$ forms estrogen response element-binding heterodimers with estrogen receptor $\alpha$. Mol Endocrinol 11:1486-1496

Pfaff DW 1980 Estrogens and Brain Function. New York: Springer-Verlag

Phillips RG, LeDoux JE 1992 Differential contribution of amygdala and hippocampus to cued and contextual fear conditioning. Behav Neurosci 106:274-285

Pierce JP, van Leyen K, McCarthy JB 2000 Translocation machinery for synthesis of integral membrane and secretory proteins in dendritic spines. Nature Neurosci 3:311-313

Price RH Jr, Lorenzon N, Handa RJ 2000 Differential expression of estrogen receptor beta splice variants in rat brain: identification and characterization of a novel variant missing exon $4^{1}$. Mol Brain Res 80:260-268

Raap DK, DonCarlos L, Garcia F, Muma NA, Wolf WA, Battaglia G, Van de Kar LD 2000 Estrogen desensitizes 5-HT 1 A receptors and reduces levels of $\mathrm{G}_{\mathrm{z}}, \mathrm{G}_{\mathrm{i} 1}$ and $\mathrm{G}_{\mathrm{i} 3}$ proteins in the hypothalamus. Neuropharmacology 39:1823-1832

Razandi M, Pedram A, Greene GL, Levin ER 1999 Cell membrane and nuclear estrogen receptors (ERs) originate from a single transcript: studies of ER $\alpha$ and $\mathrm{ER} \beta$ expressed in Chinese hamster ovary cells. Mol Endocrinol 13:307-319

Roy E, MacLusky N, McEwen BS 1979 Antiestrogen inhibits the induction of progestin receptors by estradiol in the hypothalamus, pituitary and uterus. Endocrinology 104:1333-1336

Rubinow DR, Schmidt PJ, Roca CA 1998 Estrogen-serotonin interactions: Implications for affective regulation. Biol Psychiat 44:839-850

Rudick CN, Woolley CS 2000 Estradiol induces a phasic Fos response in the hippocampal CA1 and CA3 regions of adult female rats. Hippocampus 10:274-283

Sapolsky R 1992 Stress, the aging brain and the mechanisms of neuron death. Cambridge: MIT Press; $1-423$

Sherwin BB, Tulandi T 1996 "Add-back" estrogen reverses cognitive deficits induced by a gonadotropin-releasing hormone agonist in women with leiomyomata uteri. J Clin Endocrinol Metab 81:2545-2549 
Shughrue PJ, Merchenthaler I 2000 Evidence for novel estrogen binding sites in the rat hippocampus. Neuroscience 99:605-612

Shughrue PJ, Merchenthaler I 2001 Distribution of estrogen receptor $\alpha$ immunoreactivity in the rat central nervous system. J Comp Neurol 43:64-81

Shughrue PJ, Lane MV, Merchenthaler I 1999 Biologically active estrogen receptor- $\alpha$ : evidence from in vivo autoradiographic studies with estrogen receptor $\alpha$-knockout mice. Endocrinology 140:2613-2620

Solum DT, Handa RJ 2001 Localization of estrogen receptor alpha (ER $\alpha$ ) in pyramidal neurons of the developing rat hippocampus. Devel Brain Res 128:165-175

Stumpf WE, Sar M 1976 Steroid hormone target sites in the brain: the differential distribution of estrogen, progestin, androgen and glucocorticosteroid. J Steroid Biochem 7:1163-1170

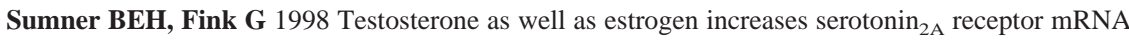
and binding site densities in the male rat brain. Mol Brain Res 59:205-214

Terasawa E, Timiras P 1968 Electrical activity during the estrous cycle of the rat: cyclic changes in limbic structures. Endocrinology 83:207-216

Teyler T, Vardaris R, Lewis D, Rawitch A 1980 Gonadal steroids: effects on excitability of hippocampal pyramidal cells. Science 209:1017-1019

Tiedge H, Bloom FE, Richter D 2001 Colloquium: molecular kinesis in cellular function and plasticity. Proc Natl Acad Sci USA 98:6997-7106

Vicario-Abejon C, Collin C, McKay RDG, Segal M 1998 Neurotrophins induce formation of functional excitatory and inhibitory synapses between cultured hippocampal neurons. J Neurosci 18:7256-7271

Wang J, Green PS, Simpkins JW 2001 Estradiol protects against ATP depletion, mitochondrial membrane potential decline and the generation of reactive oxygen species induced by 3-nitroproprionic acid in SK-N-SH human neuroblastoma cells. J Neurochem 77:804-811

Warren SG, Humphreys AG, Juraska JM, Greenough WT 1995 LTP varies across the estrous cycle: enhanced synaptic plasticity in proestrus rats. Brain Res 703:26-30

Weiland NG 1992 Estradiol selectively regulates agonist binding sites on the $N$-methyl- $D$-aspartate receptor complex in the CA1 region of the hippocampus. Endocrinology 131:662-668

Weiland NG, Orikasa C, Hayashi S, McEwen BS 1997 Distribution and hormone regulation of estrogen receptor immunoreactive cells in the hippocampus of male and female rats. J Comp Neurol 388:603-612

Wells DG, Richter JD, Fallon JR 2000 Molecular mechanisms for activity-regulated protein synthesis in the synapto-dendritic compartment. Curr Opin Neurobiol 10:132-137

Williams CL, Meck WH 1991 The organizational effects of gonadal steroids on sexually dimorphic spatial ability. Psychoneuroendocrinology 16:155-176

Witelson SF, Glezer II, Kigar DL 1995 Women have greater density of neurons in posterior temporal cortex. J Neurosci 15:3418-3428

Wong M, Moss RL 1992 Long-term and short-term electrophysiological effects of estrogen on the synaptic properties of hippocampal CA1 neurons. J Neurosci 12:3217-3225

Woolley C, McEwen BS 1992 Estradiol mediates fluctuation in hippocampal synapse density during the estrous cycle in the adult rat. J Neurosci 12:2549-2554

Woolley C, McEwen BS 1993 Roles of estradiol and progesterone in regulation of hippocampal dendritic spine density during the estrous cycle in the rat. J Comp Neurol 336:293-306

Woolley C, McEwen BS 1994 Estradiol regulates hippocampal dendritic spine density via an N-methyl-D-aspartate receptor dependent mechanism. J Neurosci 14:7680-7687

Woolley C, Gould E, Frankfurt M, McEwen BS 1990 Naturally occurring fluctuation in dendritic spine density on adult hippocampal pyramidal neurons. J Neurosci 10:4035-4039 
Woolley CS, Weiland NG, McEwen BS, Schwartzkroin PA 1997 Estradiol increases the sensitivity of hippocampal CA1 pyramidal cells to NMDA receptor-mediated synaptic input: correlation with dendritic spine density. J Neurosci 17:1848-1859

Yankova M, Hart SA, Woolley CS 2001 Estrogen increases synaptic connectivity between single presynaptic inputs and multiple postsynaptic CA1 pyramidal cells: a serial electron-microscopic study. Proc Natl Acad Sci USA 98:3525-3530

Ziv NE, Smith SJ 1996 Evidence for a role of dendritic filopodia in synaptogenesis and spine formation. Neuron 17:91-102 